\title{
Industry Concentration and Asset Quality as Determinate of Financial Per- formance: A Comparative Study of Indigenous and Foreign Owned Univer- sal Banks
}

http://doi.org/10.21272/fmir.3(2). 79-90.2019

Samuel Gameli Gadzo

Lecturer, Department of Banking and Finance; University of Eductaion Winneba, Ghana

Emmanuel Atta Anaman

Lecturer, Department of Banking and Finance; University of Eductaion Winneba, Ghana

Mavis Pobbi

Lecturer, Department of Accounting; University of Eductaion Winneba, Ghana

Samuel Kofi Asiamah

Lecturer, Department of Banking and Finance; University of Eductaion Winneba, Ghana

\begin{abstract}
This study assessed the link between industry concentration and asset quality as key determinate of financial performance through the use of the panel regression model. The sample for the study comprised 24 universal banks for the 2009 to 2018. It was found that, the financial performance of the indigenous banks was influenced by asset quality and moderating variables like capital adequacy, liquidity and bank size while the level of industry concentration does not influence the financial performance of the indigenous universal banks. The results also indicated that, the financial performance of the foreign banks is not influenced by asset quality but rather operational efficiency, liquidity, bank size and industry concentration. It is recommended that, since poor asset quality through non-performing loans adversely affect the financial performance of both indigenous and foreign banks, banks should increase their size through investment in technology to diversify the effect of asset quality on financial performance.
\end{abstract}

Key words: Industry concentration, Asset Quality, Finnacial Performance; Indigenous banks; Foreign owned banks

JEL Classification: G21, G33, G32, C13, C58.

(C) The Authors, 2019. This article is published with open access at Sumy State University.

Cite as: Gadzo S. G., Anaman, Em. At., Pobbi, M., Asiamah, S. K. (2019). I Industry Concentration and Asset Quality as Determinate of Financial Performance: A Comparative Study of Indigenous and Foreign Owned Universal Banks. Financial Markets, Institutions and Risks, 3(2), 79-90. http://doi.org/10.21272/fmir.3(2). 79$\underline{90.2019}$

\section{Introduction}

Banking sector is one which is usually characterized by high concentration of the sectors asset owned by few giant banks. Ongore, and Kusa (2013) and Wibowo (2016) opined that in order to escalate efficiency and market share, large banks tend to acquire other banks which leads to an increase in the concentration level of the banking sector. In Ghana, when the minimum capital requirement was increase from GHC 120 million approximately \$23 million to GHC 400 approximately \$77 million, the Bank of Ghana openly urged small banks to have consolidation plans to a merger between them to increase their capital. The continuous occurance of this phenomenon will lead to an increase the concentration level of banking sector in the future. According to Wibowo (2016), this theoretical scaffold surface from efficient-structure paradigm which infers that, banks with large assets size will topple other banks in the race for competition, retain earnings and expand its market share so that banking industry eventually end up concentrated than before.

Banks with large asset size can achieve economies of scale and has a natural competitive cost compared to its competitors (Hughes \& Mester, 2013; Kovner, Vickrey \& Zhou, 2014). The empirical study by Feng and Serlitis (2010) and Beccalli, Anolli and Borello (2015) suggested both USA and European large banks in terms of asset size and quality operates as a giant financial conglomerate with broad financial services and far more efficient than their smaller competitors. Feng and Zhang (2014), indicated that among other variables 
Financial Markets, Institutions and Risks, Volume 3, Issue 2, 2019 ISSN (online) - 2521-1242 ISSN (print) - 2521-1250

banking industry concentration and banks'asset quality influences the performance of banks irrespective of their ownership structure. From this backdrop, aside industry concentration of the banks, asset quality is significant variables in estimating the financial performance of universal banks. Asset quality entails the assessment of a firm asset in order to expedite the measurement of the level and size of credit risk associated with its operation. It relates to the left-hand side of a bank statement of financial position and focused on the quality of loans which provides earnings for a bank.

A bank's assets comprise mainly of its loans and advances to customers. From a shareholder's perspective, assets quality is meant to earn returns through various investments but mainly through interests from loans to customers to ensure profitability of the entity (Love, Mattews, Simpson, Hill \& Olatunji, 2014). Petajisto (2013) and Vigneswara (2015), found out that the stability of the banking stability affects the stability of any given economy. Vigneswara (2015) further asserted that the banking industry should ensure proper and high asset quality to achieve banking stability. Vigneswara (2015), also concluded that financial fragility and market crisis due to market illiquidity has contagion effect on the financial performance of banks with low asset quality. From this back drop, asset quality is considered extremely essential in corporate banking and finance because, a bank with low asset quality is likely to be exposed to huge volumes of non performing loans which was found to have a negative effect on the financial performance of banks. Nazir (2010) indicated that, the problems of asset quality precarious to the survival of banks hence financial institutions across the globe are encouraged to set up asset quality monitoring systems to mitigate the effect of low asset quality on their operations.

The asset quality monitoring systems are to identify possible emerging problems of bank asset quality and to regularly present the asset quality reports to the central banks so as to evaluate the risks associated with asset quality deterioration. The deterioration of asset quality affects it's financial performance as well as the general soundness of the financial system in which it is an entity (Barus, Muturi \& Kibati, 2017). Banks operating in countries with frail banking systems should pay more attention to managing asset quality in order to warrant the sound development of the banking industry. From this backdrop, the banking sector in Ghana has witnessed many reforms and restructuring over the years as a result of internal and external economic shocks geared towards instigating the foundation for enhanced asset quality in the banking sector of Ghana

The most recent development in Ghana's banking sector is the adjustment of the minimum capital from GHC 120 million to GHC 400 million which was effective in December 2018. Other developments include the establishment of collateral registry and credit reference bureaus that seeks to promote transparency and ease credit accessibility, the setting up of the Financial Intelligence Centre (FIC) to address money laundering and counter financing for terrorism, and the recapitalisation of the banks required by Bank of Ghana. All these measures by Bank of Ghana are believed to have been fashioned to mitigate risk and stabilize the banking system. These reforms are backed by tighter and effective supervisory oversight to ensure financial stability and soundness of the financial system. This require that banks without the wellwithout to fall on industry concentration and asset quality as means for mobilizing funds to beef up their capital base. This makes the issue of asset quatilty a relevant content for study on banks in contemporary times especially in examining the determinants of banks financial performance.

\section{Motivation for the study}

Universal banks were mandated to undertake wide range of financial services without restriction with the introduction of universal banking in Ghana in 2003 (Bank of Ghana Report, 2018). This has allowed new entrants into the banking industry some of which are foreign and indigenous banks. Though the financial sector of Ghana is dynamic, banks in this industry have recorded downward trend in their financial performance in recent times. According to the end of year report from the central bank, the average finanacial performance measured by ROA declined from 4.9 percent in 2016 to 3.7 percent by the end of 2017 and to 3.5 percent in 2018 while the average industry return on equity declined from 22.9 percent to 17.7 percent and to 16.8 percent during the same review period (Bank of Ghana Report, 2018). During the same comparative periods, the ratio of the bank's asset quality, recorded an increase from 18.8 percent in 2016 to 21.2 percent in 2017 and to 22.6 percent in 2018. Base on empirical evidences (Allen 2010; Aremu 2012; Lee \& Hsieh 2013; Barus, Muturi \& Kibati, 2017), the financial performance of commercial banks in developed countries is largely influenced by internal and macroeconomic factors. The question that stands to be answered is that, why is the increase in asset quality of the universal resulting in the decline of both ROA and ROE? Does the level of industry concentration play a key role in the determing the financial performance of banks in Ghana? 
Also from the assertion by Krakah and Ameyaw (2010) foreign based banks in Ghana performs better than the indegeneous banks, this study sought to clearly distinguish the factors that largely contribute to the performance of foreign owned banks and indigenous banks in Ghana.

\section{Literature Review}

The review of literature is subdivided into the theoretical review, empirical review and conceptual framework. The theoretical review presents perspectives on propositions and ideas of some earlier researchers, authors and educators on the theories of determinants. Under the empirical review, the research methodology, findings and recommendations of some researchers in relation to determinants of performance are reviewed. There are also theoretical models that underpin and predict the direction of the effects of the factors that affect the financial performance of banks.

\section{Theoretical Postulates}

This study is discussed on the premisis of the efficient structure theories which offers an alternative explanation to the market Structure Conduct Performance (SCP) relationship which was first initiated by Demsetz (1973) who also proposed the efficiency structure hypothesis. The theory suggests that, collusive behavior of banks does not influence their financial performance but rather the level of operational efficiency. This implies that, the efficient structure theory suggests that a bank which operates more efficiently than its competitors gains higher profits resulting from low operational costs. Consequently, differences at the level of efficiency create an unequal distribution of positions within the market and an intense concentration (Mensi \& Zouari, 2010). The efficient structure hypothesis was further expanded in two different forms depending on the type of efficiency considered.

These are the X-efficiency form and the Scale efficiency form. In the X-efficiency form, more efficient firms have lower costs, higher profits and larger market share, because they have a superior ability in minimizing costs to produce any given outputs. In the Scale Efficiency form, the same relationship described above is eminent due to the fact that more scale efficient firms produce closer to the minimum average-cost point. Empirical examination of the efficient structure theory was performed by Smirlock (1985). Using data set over 2700 banks, he found no relationship between market concentration and bank profitability, while significant positive correlation between bank profitability and market share was present. Therefore, according to his empirical work, Structure-Conduct-Performance paradigm was considered to be wrong.

\section{Empirical Review}

Sami and Zouari (2011) examined the financial performance of 34 Islamic and conventional banks in Gulf countries during the period of 1997-2004. By using multiple linear regression, the study used three financial performance indicators measures return on equity, return on assets, and net interest margin, and six internal variables such as bank's size, total equity to total assets, total loans against total assets, deposits against total assets, total expenses against total asset, and non-interest expense against total expense. It was found that, bank's size, total equity and total expenses have an inverse effect on traditional banks' profitability, whiles they have a positive effect on Islamic banks financial performance. Asset quality, had positive impact on Islamic and conventional banks performance. Deposits had a positive effect on conventional banks, but have an inverse effect on Islamic banks performance.

In a similar study, Chantapong (2005), investigates the performance of domestic and foreign banks during the period 1995 to 2000. All banks were found to have reduced their credit exposure during the crisis years and have gradually improved their profitability during the post-crisis years. The results indicated that foreign bank profitability was higher than the average profitability of the domestic banks. Athanasoglou, Brissims and Delis (2007) analyzed the effect of selected set of determinants on banks profitability in the South Eastern European. It was found that industry concentration was positively correlated with bank performance while other bank specific variables like liquidity, asset quality, bank size and age also influence performance positively but were not statistically significant.

Inaddition, Atasoy (2007) examined the determinants of performance and expenditure-income structure of Turkish banking sector between 1990 and 2005. The study established that, that ROA is affected positively by the ratio of equity, asset quality and inflation rate positively and negatively by industry concentration, ratio of banking sector asset size to national income and ratios of fixed assets and special provisional costs to total assets. This outcome was supported by Sathye, (2005), Heffernan and Fu (2008) and Sayilgan and Yildirim 
Financial Markets, Institutions and Risks, Volume 3, Issue 2, 2019

ISSN (online) - 2521-1242 ISSN (print) - 2521-1250

(2009) but futher indicated that, the type of bank is influential such that neither the percentage of foreign ownership nor bank listings has a discernible effect.

Wanzenried and Dietrich (2009) found that banks with a higher interest income share are less profitable while the effective tax rate and the market concentration rate had a significantly negative effect on the performace of banks in Switzerland. On the other hand, Davydenko (2010) used a panel of individual banks' financial statements from 2005 to 2009 in Ukrainian and indicated that, banks with low asset quality usually expirences a decline in the financial performance. Davydenko (2010) futher found that there is a significant difference in the financial performance pattern of banks with foreign capital and those which are exclusively domestically owned banks. Trujillo-Ponce (2013) also emphasized that, high volumes of capitalization had a positive effect on the return on average assets (ROAA), and negatively on the return on Average Equity (ROAE). The study also found that, the rate of growth of deposits, size and income diversification does not have an impact on banks profitability. In terms of external factors, market concentration, economic cycle, the inflation rate and the interest rate have influenced banks profitability.

From the perspective of Ghana, Kutsienyo (2012) opined that, using ROA as a measure of bank profitability, equity over total asset, expense over income, advances over deposits, provision for bad debt over advances, bank size, inflation, Gross Domestic Products (GDP), money supply and banking industry concentrate were found to be significant in determining profitability. The results indicate that well capitalised banks are more profitable as capital adequacy had a positive and significant effect on bank profitability. The results also indicate that there is a positive relationship between liquidity and profitability implying that the more liquid a bank is the more profitable it becomes. Concerning asset quality and bank profitability, asset quality measured in terms of the ratio of provision for bad debt to advances had a significant negative impact on bank profitability. This implies as the asset quality deteriorates (credit risk increases) the profitability of the bank also decreases.

Kutsienyo (2012) and Oduro, Asiedu \& Gadzo (2019). also found a significant negative relationship between operating expense and bank profitability implying that banks are not efficiently translating their expenses into profits. The findings of the study also suggest that large banks tend to enjoy economies of scales as size is positively related to bank profitability. Measuring profitability with ROE, the effects of bank-specific variables were not very much different from the results of the model with ROA. The only difference was in term of the capital adequacy variable. This variable was negatively related to profitability (ROE) contrary to the case of (ROA) where capital adequacy was impacting positively on profitability. Krakrah and Ameyaw (2010), Gadzo \& Asiamah (2018) and Gadzo (2018) also found that, non-interest income, non-interest expense, bank's capital strength, natural log of total assets, growth of money supply, and annual rate of inflation are significant key drivers of profitability of universal banks in Ghana.

From the empirical study, it can be noted that previous studies which concentrated of estimamting the determinates of banks performance between foreign and indegenoues banks did not consider asset quality and industry concentration in their estimation hence leaving a litereture gap of which this study sought to bridge. With respect to Ghana, the two studies that were found to have established the determinates of banks performance did not consider the separation of foreign banks and indigenous bank. This study therefore analysis its findling by separating the foreign banks from the indegenoues banks by making industry concentration and asset quality the centre stage of the discussion.

\section{Methodology}

This section introduces the methodology and the data source adopted for the empirical analysis of the study. There is also the need to estimate the relationship using the panel data consisting of different groups of banks in the Ghanaian banking industry (such as indegenoues banks and foreign owned banks) data across the period of 2009 to 2018. The choice of the period is dictated by several consideration. First, during this period there is an equal number of foreign owned banks and indigenous banks operating in the country hence it provides a fair bases for comparing the determinates of their financial performance. Second, the year 2009 to 2018 marks the post 2008 financial crisis era hence to avoid structural break in the analysis the post financial crises era was not considered since it is an external shock on the performance of banks in Ghana. The data for the empirical analysis has been sourced from the robust database of the bank of Ghana and Pwc Banking survey. To minimise the possibility of biased results, only firms for which data are available throughout the sample period were considered. After deleting missing values and incomplete data, the sample includes a total of 24 
(12 indegenous and 12 foreign owen) banks out of the possible 29 banks. 3 of the banks out of the 29 had issues with the regulatory body so they were not included in the analysis.

\section{Empirical Model}

To determine the dynamic and simultaneous inter-relationship between bank performance and its determinants, this study adopted an empirical model used by Berger (1995) and further made popular by authors such as Demirguc-Kunt and Huizinga (2001) and Naceur \& Goaied (2008). The model was specified as a combination of both internal variables (capital adequacy, bank size, asset quality, liquidity and operating efficiency) and external variables (bank concentration)

The models were thus specified as:

$\pi_{i t}=\alpha_{i}+\beta_{1} C A_{i t}+\beta_{2} \mathrm{Size}_{i t}+\beta_{3} A Q_{i t}+\beta_{4} L Q_{i t}+\beta_{5} O E_{i t}+\beta_{6} B I C_{i t}+u_{i t}$

where: $\pi=R O A$; $\mathrm{CA}=$ capital adequacy; $\mathrm{SIZE}=$ bank size; $\mathrm{AQ}=$ asset quality, $\mathrm{LQ}=$ liquidity; $\mathrm{OE}=$ operating efficiency; $\mathrm{BIC}=$ banking industry concentration,

$\mathrm{i}=1,2,3,4 \ldots \ldots \ldots \ldots \mathrm{n} \quad \mathrm{t}=$ years that will be used

$\boldsymbol{\alpha}_{\mathrm{i}}$ : Unobservable heterogeneity (individual effect) which is specific for each bank.

$\lambda_{\mathrm{t}}$ : Unobservable time effects.

Regression analysis was used to investigate the relationship between determinants of performance using asset quality and bank industry concentration as the centre stage for both foreign and indeginous banks in Ghana. However, to prevent multi-collinearity among the explanatory variables, a stepwise regression technique was adopted so as to achieve a more efficient parameter estimates. As a result of this, three different regression equations were generated for the foreign owned banks, the indigenous banks and finally the combined banks. In light of this, each of the variables were regressed against each dependent variable whilst maintaining the same control variables in all scenarios.

\section{Estimation Technique}

Unlike the normal pooled ordinary Least Squares (OLS) regression, Panel data regression techniques take into consideration the various biases and other disturbances that may come up in the regression analyses by controlling the unspecified differences among firm soecific variables that are not easily incorporated in practice. The study employs the panel data model below:

$Y_{\mathrm{it}}=\alpha_{i}+\theta_{\mathrm{t}}+\beta X_{j i t}+\varepsilon_{\mathrm{it}}$

$\alpha$ denotes cross sectional heterogeneous effect which is time invariant, $\theta$ is the individual heterogeneity effect, $X_{j i t}$ represents a vector of explanatory variables, $i$ represents the $i^{\text {th }}$ determinates of financial performance, $j$ is the number of independent variables and $t$ is the year. $\varepsilon$ captures the unobserved time specific effect and is the idiosyncratic error term. Since our analysis involves the use of panel data, using the ordinary least squares (OLS) method would result in ignoring the differences between different determinates of financial performance and this would have made it impossible to determine the direction of error, giving rise to heterogeneity bias. The study therefore employed the fixed effects and random effects model in its estimation. However, the major problem is in selecting between the Fixed Effect (FE) and the Random Effect model (RE) models. The FE model allows for arbitrary dependence between the unobserved effect and the explanatory variables $X_{i t}$ (Wooldridge, 2010), hence they become fixed parameters to be estimated. Here we transform the dependent and independent variables and then apply OLS to the transformed data to obtain the within estimator. The FE model alters the estimating equation so as to eliminate the fixed effects (Baltagi, 2008).

Under a random effect model the unobserved effects $\theta$ s, are assumed to be random and the estimation procedure used is the generalized least squares (GLS). The GLS uses cross-section weights for every observed determinates of financial performance at time $t$, and the true variance elements, in order to produce a matrixweighted average of the within and the between which is gotten by regressing the cross section averages across time estimators (Baltagi, 2008; Greene, 2008). It is important to mention, however, that both the fixed and random effect models assume that the errors are independently and identically distributed. This suggests the absence of heteroskedasticity and auto-correlation. When this assumption is violated, these models will yield 
Financial Markets, Institutions and Risks, Volume 3, Issue 2, 2019

ISSN (online) - 2521-1242 ISSN (print) - 2521-1250

inefficient or invalid estimates. Relaxing the assumption of independently and identically distributed residuals, this estimator produces robust standard errors if the residuals are correlated within but uncorrelated between clusters which gives rise to heteroskedasticity and auto correlation consistent estimates. In addition, estimates from the traditional Hausman specification tests are also invalid in the presence of spatial correlation. Driscoll and Kraay (1998) consequently proposed a model with residuals that are robust to very general form of cross sectional as well as temporal dependence.

Table 1. Measurement of variables

\begin{tabular}{|l|l|l|}
\hline \multicolumn{1}{|c|}{ Proxy } & \multicolumn{1}{|c|}{ Variable definitions } & \multicolumn{1}{c|}{ Predicted sign } \\
\hline CA & Ratio of annual net income to total assets & $+/-$ \\
\hline Size & Natural log of total assets & + - \\
\hline AQ & $\begin{array}{l}\text { This is the ratio of Provision for bad debt to advances. It indicates how } \\
\text { much of the total portfolio has been provided for but not charged off } \\
\text { and is used as a measure of bank's asset quality and risk. Given a similar } \\
\text { charge-off policy the higher the ratio the poorer the quality and there- } \\
\text { fore the higher the risk of the loan portfolio }\end{array}$ & $+/-$ \\
\hline OE & $\begin{array}{l}\text { Proxy adopted for liquidity calculated as liquid assets over total assets } \\
\text { or Advances over Deposits. It indicates the ability of bank to meet its } \\
\text { short-term obligations. Higher figures denote lower liquidity. }\end{array}$ & $+/-$ \\
\hline BIC & $\begin{array}{l}\text { Calculated as non interest expense over total assets. This is the expense- } \\
\text { to-income ratio. It provides information on the efficiency of the man- } \\
\text { agement regarding expenses relative to the revenues it generates. } \\
\text { Higher ratios imply a less efficient management. }\end{array}$ & $+/-$ \\
\hline & $\begin{array}{l}\text { The concentration ratio is calculated by dividing the assets of the larger } \\
\text { banks in terms of branch network by the total assets of all the banks. }\end{array}$ & $+/-$ \\
\hline
\end{tabular}

$\mathrm{CA}=$ capital adequacy, Size $=$ Bank size, $\mathrm{AQ}=$ Asset Quality, $\mathrm{LQ}=$ Liquidity, $\mathrm{OE}=$ operating Efficiency and $\mathrm{BIC}=\mathrm{Bank}$ industry concentration.

Sources: Authors construct (2019) based of reviewed literature.

\section{Empirical Results}

The empirical results are segmented into the descriptive statistics followed by the results of the huasman test and the regression results. Table 2 present the overall descriptive statistics of all the banks used in the current study. From Table 2, the average asset quality over the study period stood at 48.87 percent meaning that asset quality of the banks in Ghana is below 50 percent. This presupposes a high non-performing loan on the part of loan advances made to customers. Banks with high non-performing loans are likely to be exposed to liquidity risk which affect other operations of the banks according to the structure conduct model which indicates that, collusive behavior of banks does not influence their financial performance but rather the level of operational efficiency.

Table 2. Descriptive Statistics for the Banks

\begin{tabular}{|l|c|c|c|c|c|}
\hline & Minimum & Maximum & Mean & Std. Dev & Skewness \\
\hline & Statistic & Statistic & Statistic & Statistic & Statistic \\
\hline ROA & -6.00 & 32.00 & 11.85 & 14.85 & 2.60 \\
\hline CA & 0.20 & 1.60 & 1.32 & 18.164 & 6.01 \\
\hline OE & 0.89 & 38.82 & 46.63 & 27.93 & 5.44 \\
\hline LQ & 0.04 & 5.90 & 1.62 & 4.49 & 9.65 \\
\hline AQ & 1.97 & 56.00 & 48.87 & 30.61 & 3.81 \\
\hline SIZE & 4.56 & 12.46 & 7.36 & 1.23 & 1.42 \\
\hline BIC & 20.34 & 65.67 & 56.45 & 5.5 & 2.18 \\
\hline
\end{tabular}

Source: Descriptive statistics; 2019.

ROA had a relatively low average of about 11.85 percent which is far below the industry average recorded by the Bank of Ghana report for the years considered for the study. This implies that the ROA recorded by the banks performing well in the industry is better than those performing poorly in the industry. This is testified by the minimum and maximum statistics recorded in Table which states $-6 \%$ and $32 \%$ respectively for both measures of central tendency. This finding supports the preposition by Athanasoglou, Brissimis \& Delis (2007) and Sathye, (2005) whose study indentified extrem values for the minimum and maximum statistic 
and attributed that to unfair compition in the banking sector. Furthermore, all the firm specific variables indicated a satisfactory central tendency indicator. However out of all the firm specific variables, bank size obtaining the lowest volatility of about 1.23 percent. The liquidity of the banks is paramount since it indicates the institutions ability to effectively convert their asset into cash but with an average of 1.62 and corresponding minimum and maximum statistics of 0.54 and 2.11 respectively, it indicates that the average liquidity position of the banks in the banking sector of Ghana are well within range.

\section{The Hausman specification test}

The Hausman specification test is a test carried out on the panel data prior to running a panel data regression to establish whether the researcher should choose the fixed effects or the random effects in the model estimation. The random effects model assumes that there is no correlation between the group specific random effects and the regressors. However, the fixed effects model does not make such assumption and the possibility remains that the assumption of zero correlation in random effects model is not feasible. As a rule of thumb, if carried out and the probability value is less than 0.05 (i.e., $p<0.05$ ) then there is a correlation between the error terms and the explanatory variables so the fixed effects is adopted in the model estimation otherwise the random effects is an inefficient estimator of the parameters under investigation.

Table 3 below shows the results of the Hausman specification tests, from the results, the test statistic originally developed by Hausman has an asymptotic $\chi 2$ distribution. In testing the hypotheses the rule of thumb is that if the tests shows that the probability value is less than 0.05 (i.e. $p<0.05$ ) then there is a correlation between the error components (defined as $\mathrm{e}_{\mathrm{it}}=\mathrm{u}_{\mathrm{i}}+\mathrm{e}_{\mathrm{it}}$ ) and the explanatory variables and the fixed effects is adopted in the model estimation; otherwise the random effects is a more efficient estimator of the parameters under investigation since it establishes that the $\mathrm{u}_{\mathrm{i}}$ is random, independent of $\mathrm{e}_{\mathrm{it}}$ and the explanatory variables. The results of the $\chi 2$ test of significance as estimated in this study are summarized in Table 3.

Table 3. Chi-Square Tests

\begin{tabular}{|c|c|c|c|c|}
\hline \multirow{3}{*}{ Variables } & \multirow{2}{*}{\multicolumn{2}{|c|}{ Coefficients }} & \multirow[b]{3}{*}{ Difference } & \multirow{3}{*}{ Sqrt (diag b-V_B)) S.E } \\
\hline & & & & \\
\hline & Fixed effect & Random effect & & \\
\hline $\mathrm{CA}$ & -1.049 & -1.049 & 0.000 & 0.001 \\
\hline SIZE & 0.090 & 0.056 & 0.034 & 0.021 \\
\hline $\mathrm{AQ}$ & -0.144 & -0.196 & -0.052 & 0.042 \\
\hline LQ & 0.447 & 0.486 & -0.040 & 0.028 \\
\hline $\mathrm{OE}$ & 0.076 & 0.078 & -0.002 & 0.005 \\
\hline $\mathrm{BIC}$ & -0.402 & -0.405 & -0.003 & 0.003 \\
\hline \multicolumn{5}{|c|}{$\mathrm{b}=$ consistent under Ho and $\mathrm{Ha}$; obtained from $\mathrm{xtreg}$} \\
\hline \multicolumn{5}{|c|}{$\mathrm{B}=$ inconsistent under Ha, efficient under Ho; obtained from xtreg } \\
\hline \multicolumn{5}{|c|}{ Test: Ho: difference in coefficients not systematic } \\
\hline \multicolumn{5}{|c|}{$\mathrm{Chi}^{2}(6)=(\mathrm{b}-\mathrm{B})^{\prime}\left[\left(\mathrm{V} \_\mathrm{b}-\mathrm{V} \_\mathrm{B}\right)^{\wedge}(-1)\right](\mathrm{b}-\mathrm{B})=0.91$} \\
\hline \multicolumn{5}{|c|}{ Prob $>$ chi2 $=0.9888$} \\
\hline
\end{tabular}

Source: Financial ststement of universal banks 2009-2018.

The results from the Hausman test indicate that we fail to reject the null hypothesis that, the difference in coefficients is not systematic and as such we estimate a random effect model for the revenue of determinates of financial performance.

\section{Industry concentration and Asset quality as determinates of Financial performance of indige- nous banks}

Table 4 presents the regression results of return of Asset (ROA) as the dependent variable for the indigenous banks between 2009-2018. The adjusted R squared is 0.8778 for the variables used in the study. As the major independent variables which indicates that about 87.7 percent of the variability of debt ratio is explained by the bank specific and macroeconomic factors; about 86 percent of the variability of total debt ratio is explained by the firm specific and macroeconomic.

The F-statistic of 70.538 respectively suggests that the model fits the data significantly. The Durbin-Watson statistic has a value of 2.176 indicates the absence of autocorrelation problem. From the analysis capital adequacy, liquidity, asset quality and bank size are the main determinants of performance due to the significance of their t-test and their significant values. 
Table 4. Regression for Indigenous Banks

\begin{tabular}{|l|l|l|l|l|}
\hline Dependent Variable: ROA & \multicolumn{2}{l|}{} & \\
\hline Variable & Coefficient & Std. Error & t-Statistic & Prob. \\
\hline C & 3.412 & 4.713 & 0.724 & 0.516 \\
\hline OE & 1.7753 & 0.968 & 1.834 & 0.072 \\
\hline CA & -0.487 & .114 & -4.273 & 0.000 \\
\hline LQ & 4.460 & 2.017 & 2.211 & 0.000 \\
\hline AQ & -2.777 & 1.321 & -2.102 & 0.039 \\
\hline SIZE & 6.567 & 1.317 & 4.986 & 0.000 \\
\hline BIC & -2.069 & 1.238 & -1.672 & 0.516 \\
\hline R-squared & 0.8778 & \multicolumn{2}{|l|}{ Mean dependent var } & 47.25209 \\
\hline Adjusted R-squared & 0.7705 & S.D. dependent var & 222.4666 \\
\hline F-statistic & 70.538 & Durbin-Watson stat & 2.175662 \\
\hline Prob(F-statistic) & 0.0000 & \multicolumn{2}{|l}{} \\
\hline
\end{tabular}

Source: Financial statement of idegenous universal banks from 2009-2018.

Bank size does not show a negative association with ROA as expected as its coefficient of 6.567 revealed a positive association with the ROA of the indigenous banks which is also statistically significant. From Table 4 , it can be observed that capital adequacy and liquidity are important in determining the financial performance in the banking sector of Ghana. They are all significant at 5 percent. The result also shows a positive relationship exists between liquidity and ROA as its coefficient is significant at 5 percent. This implies that, an increase in liquidity of the indigenous banks in Ghana, all other determinants variables held constant, their performance also increase. The reason is that, liquidity shows that banks are not overtrading and for that matter attracks a lot of customers to their operations which will eventually result in an increase in interest income. It is crucial to note that whether liquidity would have a significant effect on returns on asset or not depends on the extent to which the liquidity is used to attract more clients.

Assuming deposits are taken but are not efficiently utilized in liquidity management, the banks will struggle to meet daily demand of cash by their customers.Similarly, if deposits are taken and given out a loans and there is high default rate, it is again expected that debt will have little or no effect on returns on asset. This outcome was expected because whenever a bank is operationally efficient, it always honours its current liabilities as proposed by the expense-preference behavior theory. The main goal which managers pursue is to maximize not profit but own utility or utility of the firm, which is usually achieved through increasing salaries (Beccalli, Anolli \& Borello, 2015). This means that indigenous banks have the capability of increasing their interest incomes. The reason for this is that after taking custody of these funds, they engage in asset transformation by converting it into various denominations for their clients to demand with an interest component which is in their ultimate interest. This seems to be the case in Ghana especially before the periods of 20092018. when doubtful debts were astronomically high.

Table 5 presents the regression table for the ROA for the indigenous banks. The adjusted $\mathrm{R}$ for the model was 0.7528 respectively which indicates that about 75.28 percent respectively of the variability of ROA is explained by the firm specific, macroeconomic factors and the determinants of performance variables. The Fstatistic which ranged from 20.521 suggests that the model fits the data significantly. A Durbin-Watson statistic which also ranged from 2.273 also indicates the absence of autocorrelation problem.

Table 5: Estimtion results for Foreign Banks

\begin{tabular}{|l|l|l|l|l|}
\hline \multicolumn{5}{|c|}{ Dependent Variable: ROA } \\
\hline Variable & Coefficient & Std. Error & t-Statistic & Prob. \\
\hline C & 3.141 & 2.051 & 1.531 & 0.146 \\
\hline OE & 0.279 & 0.135 & 2.067 & 0.049 \\
\hline CA & 0.418 & 2.009 & 0.208 & 0.811 \\
\hline LQ & 1.021 & 0.417 & 2.448 & 0.016 \\
\hline AQ & -7.164 & 2.327 & -3.079 & 0.002 \\
\hline BS & 0.797 & 0.517 & 3.476 & 0.001 \\
\hline BIC & -2.091 & 1.009 & -2.072 & 0.046 \\
\hline R-squared & 0.7528 & Mean dependent var & 39.1209 \\
\hline Adjusted R-squared & 0.6113 & S.D. dependent var & 12.4549 \\
\hline F-statistic & 20.521 & Durbin-Watson stat & 2.27302 \\
\hline Prob(F-statistic) & 0.0000 & \multicolumn{2}{l}{} & \\
\hline
\end{tabular}

Source: Author's Regression. 
From Table 5 the significant values, indicates that among the factors, operational efficiency, liquidity, asset quality, bank size and bank concerntrtion significant at 5 percent significance level with a positive been positive with the exception of asset quality and bank concerntration having a negative relationship. While, operational efficiency and size appears to be significant at 5 percent significance level with a negative coefficient. From the results, asset quality had negative relationship with return on asset with a reltively higher coefficient of -7.164. This means that as the asset quality increases, the performance of the banks fall. The reason is that the performance of banks is independent of their assets so instead of improving the asset quality, those assets should be transformed in a manner which will lead to more interest income to the banks.

This evidences a strong support for the efficient structure theory, whereby available internal funds would reduce the tendency of companies taking additional debt. Bank size and liquidity reflects strong positive association with ROA as evidenced by the coefficient of 0.797 and 1.021 respectively. A 1 percent increase in the bank size and liquidity (keeping another variables constant) would bring more than a percent increase in ROA. Assuming other variables constant, a 1percent increase in the companies' debt would increase the tendency foreign banks making a profit by more than 3 percent. Though the relationship is not statistically significant, from this analysis it can be observed that foreign banks comply to the Structure-Conduct-Performance (SCP) paradigm of determinants of performance in addition to the efficient structure theory. To add to the above, debt does not influence returns on asset significantly in the foreign banks of Ghana. This is evidence as dividend payout ratios are small or in most cases nil in the sector. The evidence in Ghana is that, the levels of retained earnings continue to ascend on the books of most foreign banks thus depriving shareholders of dividends at least in the short-run (Ghana Banking Report, 2018). Another reason for the insignificance of debt in influencing returns on asset is as a result of increasing costs in doing the business of banking in emerging economies including Ghana. The resultant effect of this is that it reduces profits which could have gone to shareholders, all else equal. These costs include increasing employee salaries, investments in information technology, acquisition and maintenance of chauffeured premises, and finally increasing cost of raising deposits. These costs are discussed in turn. The cost of hiring and maintaining employees continue to increase in the banking sector of Ghana. Global complexity of banking as a result of the advent of computer-based technology and increasing customer desire for ground-breaking products and services has called for the engagement of very skilled personnel for effective and efficient management of all these demands in order to remain profitable and competitive (Ghana Banking Report, 2018).

To achieve this, it is crucial for us to note that heavy costs are often incurred, which significantly reduces shareholders' wealth. The worst scenario is when the benefits of these employees do not achieve results more than compensate significantly to the cost of hiring them. Furthermore, the cost of investment in information technology has also undoubtedly increased the cost of doing business in the banking sector of Ghana. For example, the cost of installing satellites, automated teller machines, telephone lines and other information technology devices have all escalated costs on the books of the various banking firms in Ghana. Consequently, this would affect profits adversely and thus shareholders' wealth, all else equal. What we must appreciate at this point is that very often than not, it's the net returns on loans given out by the foreign banks that is primarily used in offsetting the above-mentioned costs among other things (Hughes \& Mester, 2013).

It is therefore intuitive that if significant portions of this income are used in compensating for costs, then banking profits which is mainly a function of net returns on loans will fall. Thus, the insignificance of debt in determines returns on asset in the banking sector of Ghana is not surprising. Another group of overheads, which is reducing foreign banks profit in Ghana and therefore shareholders' wealth thus making deposits insignificance in influencing returns on asset, is acquisition and maintenance of chauffeured premises. In Ghana, most banking groups believe that one of the ways to attract clients is to operate from expensive, well decorated and furnished premises.

This practice makes the banking halls attractive and comfortable to customers but would however build up costs, which if they can be reduced would make banking firms more profitable and competitive in Ghana. Last but not least is the increasing cost of raising debt. There is an increase competition in the banking sector of Ghana due to global deregulation of the financial services sector and the gains that abounds in banking in Ghana (Ghana Banking Report, 2018). This has led to the influx of many foreign indigenous banks mostly from Nigeria onto the soils of Ghana. To remain competitive and profitable therefore, banking firms in Ghana have embarked on aggressive advertisements and other forms of campaigns to increase their customer base. In light of this, frequent adverts and many sales personnel have been used as a tool to attract customers for 
the various banking firms. This also builds up cost which reducesindigenous banks' margins and therefore shareholders' wealth especially when the cost of these adverts and campaigns far outweighs the benefits, they bring to the various banking groups.

From Table 5, Bank size defined as logarithm of total Asset has been used as a control variable and thus the quest to see how it would influence return on asset. The results revealed that bank size enters the regression equation as negative with returns on asset (ROA) and is statistically significant at 5 percent. This means that in the banking sector of Ghana, size is important in determining foreign banks profit. However, what is important for us to note is that as bank size increases bank profitability falls in Ghana and vice versa based on the evidenced revealed. The negative relationship between bank size and returns on asset or profitability suggests that larger foreign banks tend to exhibit lower margins and is consistent with models that emphasize the negative role of size from scale inefficiencies. This agrees with previous empirical works such as (Mensi \& Zouari, 2010).

\section{Comparison of the Performance Between the indigenous banks and the foreign based banks}

To compare the difference among the financial performance of the indigenous banks and the foreign based banks, a regression result is presented in Table 6 with its corresponding analysis. Result of sample regrouping regression result test shows that there is a significant difference between indigenous banks and the foreign based banks with respect to liquidity ratio $T$ - test $=4.460$ and 1.021 are different making that of the indigenous banks coefficient statistically significant. Again, the result of the asset quantity also shows that T-test for the indigenous banks and the foreign based banks is -2.777 and that for foreign banks is 3.079. It means that there is a significant difference between how the asset quality of the banks influnec the performance of the two banks.

Table 6. Comparison of the determinants of the performance of Indigenous and foreign banks

\begin{tabular}{|l|c|c|c|c|}
\hline \multirow{2}{*}{ Variables } & \multicolumn{2}{c|}{ Indegenous banks } & \multicolumn{2}{c|}{$\begin{array}{c}\text { Foreign banks } \\
\text { Co-eff }\end{array}$} \\
\cline { 2 - 3 } & Co-eff & T-test & 3.141 & 1.531 \\
\hline Constant & 3.412 & 0.724 & $0.279^{* *}$ & 2.067 \\
\hline OE & 1.7753 & 1.834 & 0.418 & 0.208 \\
\hline CA & $-0.487^{* *}$ & -4.273 & $1.021^{* *}$ & 2.448 \\
\hline AQ & $4.460^{* *}$ & 2.211 & $-7.164^{* *}$ & -3.079 \\
\hline BS & $2.777^{* *}$ & -2.102 & $0.797^{* *}$ & 3.476 \\
\hline BIC & $6.567^{* *}$ & 4.986 & $-2.091^{* *}$ & -2.072 \\
\hline * Significance at the .10 level. & $-2.069 \quad-1.672$ & & \\
\hline
\end{tabular}

Based on the findings the asset quality of the banks negatively influences their performance but that of the foreign banks influences them more than that of the indegeneous banks. Again, from the analysis, there is a difference between the bank size as a determinante of the performance of both banks because even though both influence performance positively, that of the indegeneous banks is high that the by about 5 percent. Furthermore, all the variables that positively influence the performance of the banks, operational efficiency had the least effect on the performance of both banks because of the recorded coefficient of 1.7753 and the coefficient of 0.279 . From their t-test, that of the indegeneous banks influence them more than the foreign banks. All in all, it can be summarised that base on the difference in the T-test, there is a difference in the determinantes of the financial performance of both banks.

\section{Conclusion}

Universal banks play a key role in the economic development of every country. The study investigated the determinantes of performance of foreign and indigenous banks. Using panel data methodology, it was discovered that in relation to, the indigenous banks, the major determinantes of the performance of the indigenous banks were capital adequacy, liquidity, asset quality, bank size. Most of the established relationships were statistically significant, it is also concluded that as the performance of the bank's increases, it increases along side liquidity, asset quality and bank size. It is also found that operational efficiency, liquidity, asset quality, bank size and bank concentration are the determinantes of the financial performance of the foreign banks. The study also found that profitable foreign banks depend more on internal sources of financing thus supporting the other theory. 


\section{Recommendations}

This study recommends that care has to be taken when banks increase their asset quality. As high maintenance cost would adversely affect their financial performance, managers must always be alert on the level of asset quality to avert the adverse effect it has on the financial performance. Universal banks in Ghana must not be only interested in ensuring liquidity but must also be concerned with utilising these debts effectively and efficiently. Futher efforts must also be geared towards prudent cutting down of costs of debt and other ancillary cost in the banks in Ghana. The government, through Bank of Ghana, must develop our bond market so that banks can raise a lot of long-term debt which they need to meet their short to medium term loan operations. Recommedation for future studies in this area should be focused on the usage of the covariance approach structural equation modle in the analysis since the financial performance variables for banks are more than one and also to capture how the dependent variable (financial performance) also influenecs the independent variables. Finally, future studies should be made on the determinantes of risk adjusted performance indicators.

\section{Reference}

1. Allen, R.F. (2010). Scale-Related Efficiencies as a Source of the Profits-Market Share Relationship, Review of Economics and Statistics,71(1), 523-26.

2. Aremu, M. A. (2012). Starting a New Business and Challenges of Doing Business in Nigeria in General Studies in the Social Sciences: Some Fundamental Topics,

3. Atasoy, H. (2007). Expenditure-Income Analysis in Turkish Banking Sector and Determinants of Profitability. Unpublished Dissertations of Senior Specialists, Central Bank of Turkey, Ankara.

4. Athanasoglou, P., Brissimis, S. N. \& Delis, M. D. (2007). Bank specific, industry specific and macroeconomic determinants of bank profitability. Journal of International Financial Markets, Institutions and Money 18(2), 121-136. doi: 10.1016/j.intfin.2006.07.001.

5. Baltagi, B. (2008). Econometric analysis of panel data, John Wiley \& Sons

6. Bank of Ghana Report. (2018). Summary of economic and financial data. Retrieved from https://www.bog.gov.gh/ Monetary-policy/press releases/2851-mpc-press- release-jan-2017

7. Barus, J., Muturi, W., \& Kibati, P. (2017). The Effect of Asset Quality on The Financial Performance of Savings and Credit Societies in Kenya. American Journal of Finance, 1(4), 13-25.

8. Beccalli, E., Anolli, M. \& Borello, G. (2015). Are European banks too big? evidence on economies of scale. Journal of Banking and Finance, 16(12), 232-246.

9. Berger, A. N. (1995). The Relationship between Capital and Earnings in Banking. Journal of Money, Credit and Banking, 27(2), 432-456.

10. Chantapong, S. (2005). Comparative study of domestic and foreign bank performance in Thailand: The regression analysis. Economic Change and Restructuring 38(1),65-79.

11. Davydenko, A. (2010). Determinants of Bank Profitability in Ukraine. Undergraduate Economic Review: $7(1), 23-46$.

12. Demirguc-Kunt, A. \& Huizinga, H. (2001). Financial Structure and Bank Profitability. In Financial Structure and Economic Growth: A Cross-Country Comparison of Banks, Markets, and Development. Policy Research Working Paper Series 2430. The World Bank.

13. Demsetz, H. (1973) Industry Structure, Market Rivalry and Public Policy. Journal of Law and Economics, 18(3), 56-97.

14. Driscoll, J. C, \& Kraay AC (1998) Consistent covariance matrix estimation with spatially dependent panel data. Review of economics and statistics, 80(12), 549--560

15. Feng, G. \& Serlitis, A. (2010). Efficiency, technical change and returns to scale in large U.S. Banks: Panel data evidence from an output distance function satisfying theoretical regularity. Journal of Banking and Finance, 34(12), 127-138.

16. Feng, G. \& X. Zhang (2014). Returns to scale at large banks in the US: A random coefficient stochastic frontier approach. Journal of Banking and Finance, 39(1), 135-145.

17. Gadzo, S. G. (2018). Non-Performing Loan and Liquidity of Universal Banks: Does Minimum Capital Requirement Matters? The Journal of Social Sciences Research, 4(12).791-801.

18. Gadzo, S. G., \& Asiamah, S. K. (2018). Assessment of the relationship between leverage and performance: An empirical study of unlisted banks in Ghana. Journal of Economics and International Finance, 10(10).123-133.

19. Greene, W.H. (2008). Econometric Analysis. India: Pearson Education. 
Financial Markets, Institutions and Risks, Volume 3, Issue 2, 2019

ISSN (online) - 2521-1242 ISSN (print) - 2521-1250

20. Heffernan, S. \& Fu, M. (2008). The Determinants of Bank-Performance in China. EMG Working Paper Series No. 032008.

21. Hughes, J. P. \& Mester, L. J. (2013). Who said large banks don't experience scale economies? evidence from a risk-return-driven cost function. Journal of Financial Intermediation, 22(4), 559-585.

22. Kovner, A., Vickrey, J.\& Zhou, L. (2014). Do big banks have lower operating costs? Federal Reserve Bank of New York Policy Review, 20(2), 1- 27

23. Krakrah, A. K. \& Ameyaw, A. (2010). The Determinants of Bank"s Profitability in Ghana, The Case of Merchant Bank Ghana Limited (MBG) and Ghana Universal Bank (GCB). A Master's Thesis in Business Administration, MBA programme, 2010.

24. Kutsienyo, L. (2012). The determinant of profitability of banks in Ghana. Unpublished MBA Thesis. Kwame Nkrumah University of Science and Technology.

25. Lee, C. \& Hsieh, M. (2013). The impact of bank capital on profitability and risk in Asian Banking. Journal of International Money and Finance, 32(6), 251-281.

26. Love, P., Matthews, J., Simpson, I., Hill, A., \& Olatunji, O. (2014). A benefit realization management building information modeling framework for asset owners. Automation in Construction, 37(1), 1-10.

27. Mensi S. \& Zouari A. (2010), Efficient Structure versus Market Power: Theories and Empirical Evidence, High School of Business of Tunis (ESCT), Manouba University Higher Business Studies Institute (IHEC), University of the 7th November at Carthage.

28. Naceur, S.\& Goaied, M. (2008). The determinants of commercial bank interest margin and profitability: Evidence from Tunisia, Frontiers in Finance and Economics. 5(1),106-130.

29. Nazir, S. (2010). Analyzing Financial Performance of Commercial Banks in India: Application of CAMEL Model. Pakistan Journal of Commerce and Social Sciences. 4(1), 40- 55.

30. Oduro, R., Asiedu, M.A. \& Gadzo, S. G. (2019). Impact of credit risk on corporate financial performance: Evidence from listed banks on the Ghana stock exchange. Journal of Economics and International Finance, 11(1).1-14.

31. Ongore, V., and Kusa, G. (2013). Determinants of Financial Performance of Commercial Banks in Kenya. International Journal of Economics and Financial Issues. 3(1), 237-252.

32. Petajisto, A. (2013). Active share and mutual fund performance. Financial Analysts Journal, 69(4), 7393.

33. Sami, M. \& Zouari A. (2011). Banking Industry, Market Structure and Efficiency: The revisited model to intermediary hypothesis, International. Journal of Economics 2(1), 23-36 ISSN: 2229-6158

34. Sathye, M. (2005). Market Structure and Performance in Australian Banking, Review of Accounting and Finance, 4(2), 107-122.

35. Sayilgan, G. \& Yildirim, O. (2009). Determinants of Profitability in Turkish Banking Sector: 2002-2007. International Research Journal of Finance and Economics, 34(8),160-167.

36. Smirlock, M. (1985). Evidence on the (Non)Relationship between Concentration and Profitability in Banking. Journal of Money, Credit and Banking,17(23),69-83.

37. Trujillo-Ponce, A. (2013). What determines the profitability of banks? Evidence from Spain. Accounting and Finance. 53(12), 561-586.

38. Vighneswara, S. (2015). Modelling Bank Asset Quality and Profitability: An Empirical Assessment. Economics Discussion Papers, No 2015-27, Kiel Institute for the World Economy. http://www.economicsejournal.org/ economics/discussion papers/2015-27

39. Wanzenried G. \& Dietrich A. (2009). What Determines the Profitability of Commercial Banks? New Evidence from Switzerland, Research Paper, Institute of Financial Services IFZ, Lucerne University of Applied Sciences

40. Wibowo, B. (2016). Bank scale of economies, banking industry concentration, and competition level: The Indonesian case. Journal Business \& Management 17(1), 58-72.

41. Wooldridge, J. M. (2010). Econometric analysis of cross section and panel data. MIT press. 